\title{
Women Were Not Created of Inferior Celestial Material
}

\section{Why Treating Women as Second-Rate Beings Is IlLOGICAL}

To be fair, I have not myself come across anyone making the argument that God created women from an inferior essence or substance as such relative to men.

But since women are often treated as second-rate beings in many Muslim communities, it unfortunately seems necessary to begin by addressing this issue. The view that women are intrinsically inferior to men may not be openly articulated, but perhaps it is what shapes the mind-set that enables some societies that claim to follow a religion of "justice" to nonetheless subdue and even subjugate half of their population.

So how might this have happened? How can any follower of a religion so explicitly focused on the question of justice feel at ease with treating women so differently to men, including on such fundamental issues as dignity and spirituality?

One logical conclusion would be to assume that the prophet of Islam, Muhammad, must have treated women as inferior and so set the tone for all but the most enlightened and independent of his followers through the centuries. The problem with this theory, however, is that the historical record unambiguously shows the diametric opposite of such a conclusion, depicting a leader and family man with the comportment of both a thoughtful and conscientious individual with respect to issues of women's dignity and inalienable capacity. Many Islamic scholars-both Muslim and

(C) The Author(s) 2022

L. El-Ali, No Truth Without Beauty, Sustainable Development

Goals Series, https://doi.org/10.1007/978-3-030-83582-8_5 
otherwise-have touched on the topic of Muhammad's interactions and dealings with women, usually as part of a book, chapter or article covering a broader theme. These references leave us in no doubt that Muhammad's attitude and agenda regarding women were highly evolved for the seventh century and represented nothing short of advocacy in a far-from-compliant environment. Yet despite the pushback he encountered, women appear to have had more rights under his leadership than they do in some Muslim communities today, fourteen centuries on-surely a veritable betrayal of his example and, therefore, of his understanding of the Qur'an.

Another logical conclusion would be to assume that the holy book of Islam, the Qur'an, simply neglects to discuss women, much less address them in any way, leaving a vacuum that could easily be filled by whatever trends in a given society. Yet the Qur'an mentions, discusses, and addresses women as a group often, with one of the longest chapters in fact entitled "Women".

A third logical conclusion would be to assume that the Qur'an actually establishes women's intrinsic inferiority in no uncertain terms, making the matter definitive for ardent Muslims. Yet once again, this is not the case and in fact, nothing could be further from the truth, as will be shown in the following section by examining specific verses from the Qur'an as they relate to the nature of women.

\section{Qur'anic Verses on the Creation and Origin OF WOMEN}

Here are some verses from the Qur'an that specifically touch upon the question of women's nature as created by God, in the order they appear in the Qur'an. Both the name and number of the chapter (sura) are listed, followed by the number of the verse cited within that chapter. So the very first verse shown below comes from the chapter entitled "Women", which is Chap. 4 , and is verse 1 .

$\checkmark$ Women, 4:1

Oh humankind: Reverence your Lord, who created you (pl.) from a single soul and from it created its mate, and from the two of them disseminated multitudes of men and women; and reverence God, Whose name you invoke to one another, and the wombs [i.e. the human creation]; for God is always watching you. 
This is the foundational verse on the creation and nature of women and so warrants somewhat detailed attention, partly because its more usual translation-cum-interpretation renders the last part of it essentially as follows:

$\times \quad \ldots$ and reverence God, in Whom you make claims of one another, and the wombs [i.e. family ties]; for God is always watching over ${ }^{1}$ you.

But I also say this because I feel that often, this verse is inadvertently glossed over so that some of its foundational content is missed, as unpacked below.

It is widely accepted that the first part of the verse is a reference to Adam and Eve, given the declaration that from the two of them countless men and women were then spread forth. Notice that in this and other articulations on the creation and nature of men and women (also shown in this section), the Qur'an never says anything about who came first, Adam or Eve, so that the emphasis remains solidly on the declaration that all men and women-Adam and Eve's descendants-come from the same soul i.e. are spiritually the same. Now we do hear of Adam referred to as though he is the representative or godfather of humankind, but that comes elsewhere in such verses that recount Satan's fall from grace for refusing the divine order to bow to Adam, verses addressing humankind as the Children of Adam, and so on, which is unsurprising given the predominant cultural custom of linking descendants to their male ancestors.

If we read this verse carefully, part by part, this is what it tells us regarding the origins of the human race:

- Adam and Eve were created from the same soul

- Adam and Eve were created as "mates" i.e. together forming "a pair"

- All men and all women emanate from Adam and Eve, the original human pair

- Thus all men and all women emanate from the same soul as Adam and Eve

\footnotetext{
${ }^{1}$ Most translations of the last sentence of verse 4:1 render it essentially as "...truly God is watching over you" instead of simply "...watching you", as I have. The former is a literal translation from Arabic to English which unfortunately overlooks the fact that to "watch over" in English (at least today) has a very different meaning from "to watch". Moreover, it makes a lot more sense that God would demand reverence three times and then warn us that $\mathrm{He}$ is always watching us, rather than insistently demanding reverence and suddenly switching tones to say that $\mathrm{He}$ is always protecting (watching over) us anyway.
} 
Therefore this verse clearly establishes the spiritual sameness of men and women, and indeed of all human beings regardless of gender, race, or other physical or indeed mental differences.

It also establishes the concept of a mate (zawj), which literally means "one member of a pair" or simply "pair", depending on how it is used, and is also the word for "spouse".

But the verse does not end there, which would have made for a natural stop. No: having established the spiritual sameness of all human beings, the Author then continues, within the same verse, with the following:

- That we must reverence God as we contemplate Him

- That we must reverence every member of His human creation (the wombs)

- That He is ever-watchful

It is hard for me to think of a more comprehensive or clearer articulation of the spiritual or "human" equality of all men and women in God's eyes.

But the standard interpretation of "wombs" in this verse has not usually been "womb contents", so to speak, but rather "womb relations" or family ties. I can understand why this has been the norm: in other verses where "wombs" appears in a metaphoric way $(8: 75,47: 22,60: 3)$, indeed the reference cannot be to anything but "blood relations" or family ties. But I find it hard to relate to such an intention for the word "wombs" in this case for three reasons:

- In this verse, God is demanding no less than reverence-that we be in awe - which is an attitude we as human beings are to have towards Him and no other. This is an exclusivity every Muslim instinctively understands, but is one that I feel has been lost in conventional attempts to communicate this particular verse.

To put it differently, it sounds uncharacteristic for God to be demanding reverence (taqwa) for Himself as our Creator and for our velatives.

Whereas demanding reverence for Himself as our Creator and for all His human creation (the wombs) is surely both profoundly fitting in the context, and of immense significance. 
- In this three-part verse on the origin of the human race and its creation process, it seems natural to keep the focus on God the Creator, His creation process and His creation results, while demanding a corresponding attitude of reverence or awe from us. To mention other people here, like our relatives, seems rather incongruent as part of the creation narrative.

- Lastly, that this is the very first verse one encounters in the Qur'an on the subject of the creation and nature of women, and that it is the opening verse of the chapter entitled "Women" which deals with a large number of women's issues, is surely no coincidence. Where would be a more fitting location in the Qur'an for establishing the fundamental nature of women?

In its totality, surely this verse contains everything we need to know about human spirituality and the intrinsic worth it bestows equally on each one of us, whatever our gender or indeed colour, ethnicity, culture or social class.

A note is in order on the divergence of custom from scripture regarding verse $4: 1$.

In popular custom, people will usually quote only the first half of the first part of this three-part verse, specifically "...(He) created you from a single soul and from it created its mate....".

The problem with this abridging habit-which I have long been guilty of myself, thanks to the sheer weight of collective repetition-is threefold:

- While this is lovely in and of itself, it does not necessarily convey the spiritual equality of all of the descendants of Adam and Eve-nor allow the tracing of women's nature back to the divine breath (since we are told elsewhere that God fashioned the human being from clay and water and then breathed into it of His Spirit-15:28-29, 32:7-9, 38:72).

- On its own, the abridged form of this verse can even sound as though one gender (the male) was the main act of creation and that the other (the female) was only created to be his mate, and as though men were an extension of Adam himself rather than of both Adam and Eve.

- And obviously, the abridged version cannot possibly convey the correlation God establishes between the intrinsic nature of our souls and our attitude towards all that comes from His 


\section{creation process-and how both things are so important to God that $\mathrm{He}$ warns that $\mathrm{He}$ is always watching us.}

This is a good example of the importance of reading a verse in its entirety. But it is also an example of how important it is to take note of the Qur'anic context, as mentioned in the Preface, which can include taking note of the actual location of a verse.

\section{$\checkmark$ The Cattle, 6:98}

And it is He who made you (pl.) from a single soul, thus a dwelling-place and a repository [i.e. for you in one another]. We have spelled out the verses/signs clearly for those who understand.

I have always understood verse 6:98 to be about the human couple, as shown in the brackets above, primarily because the first part of the sentence "He made you from a single soul..." is essentially the exact wording usually deployed in the Qur'an just before describing human beings as having been created as "mates to one another" or as "pairs"2 (see previous verse and other verses in this section). In fact, one particular verse-30:21is virtually identical also in structure, in that the second sentence claims that the first sentence is a sign for people who reflect or understand. Here is 30:21 for comparison:

And among His signs is that He created mates for you (pl.) from your own souls so that you may find tranquillity in them, and established between you love and compassion. In this there are signs for people who reflect. (30:21)

However in looking up the English translations of this verse, I did not come across any that took it as a reference to the relationship between men and women, but rather to the human condition in general: rather than "thus", these translations use "and" to link the two parts of the first sentence, thereby severing the correlation between them that I hear. The most common translation of verse 6:98 is essentially the following:

\footnotetext{
${ }^{2}$ There is only one verse, $31: 28$, that speaks of the creation of human beings from a single soul in a completely different context, namely the creation and resurrection of humankind in its entirety as a single soul. And as I will explain in this section, the usual interpretations also regard verse 6:98 as not referring to the relationship between human couples, although I disagree.
} 
$\times$ And it is He who produced you (pl.) from a single soul, and (has given you) a dwelling-place [i.e. womb or life on earth] and a repository [i.e. male loins or final resting place after death]. ${ }^{3}$ We have detailed/expounded the signs for people who understand.

This more common interpretation totally erases verse 6:98's tender description of the intended relationship between the human couple, replacing it with a combination of philosophical and eschatological meanings that do not resonate at all, for two reasons:

- Other verses in the Qur'an that begin in a similar way usually proceed to tell us that God's creation of human pairs from the same essence is so that they may dwell together in tranquillity, love and mercy (besides the virtually identical 30:21 above, see also 7:189 below), so it makes sense for God to be telling us here that we were made for being together in stability (dwelling-place) and trust (repository): as the Qur'an tells us throughout the book, it speaks to us in analogy (including parables) ${ }^{4}$ and not just directly or literally, and it is prone to repeating fundamental themes over and over again for emphasis.

- As we shall see, the three verses before 6:98 and the one immediately after it are a list of the "proofs of God", so to speak, through His transcendent omnipotence and beneficence-for those who know, understand, believe. Several verses in the Qur'an-shown in this section-tell us that one such proof is God's creation of the human couple from the same essence, so the first interpretation fits the context perfectly. Here are the points made in verses 6:95-6:99 in brief to help the reader get a sense of the flow:

\footnotetext{
${ }^{3}$ There is one other verse in the Qur'an that mentions "a dwelling-place and a repository", 11:6, where the context is explicitly about God knowing everything about every creature on earth, including its "dwelling-place and repository". In that case, I agree with the rendering of these terms as "life on earth" and "place after death" given the context, but cannot help but find them somewhat unintuitive for 6:98.

${ }^{4}$ References in the Qur'an to God "striking an analogy" to make things clearer to us, and the deployment of certain parables, are too many to list, but examples include 30:58, 39:27, $47: 3$ and $59: 21$.
} 
- It is God who splits the grain and the pit, and who brings forth the living from the dead, and the dead from the living: how then are we still drawn to perverted beliefs?

- It is He who causes the dawn to break and who made the night for resting and the sun and moon for measuring/reckoning

- It is He who made the stars for us so we can be guided in darkness on land and sea: these are clear signs for people who know

- And it is He who created us from a single soul, thus a dwelling-place and repository: these are clear signs for people who understand (6:98)

- And it is He who causes rain to fall from the sky, causing all plants including vegetation, grains, fruit etc. to grow: these are clear signs for people who believe

Given the reasons above, I find the most intuitive meaning of 6:98's "dwelling-place" and "repository" to be a description of the reciprocity between members of the human couple due to their very nature: since they come from a single soul.

I find it impossible to relate to the most common interpretation, which holds that they refer to the female womb and loins of the male, ${ }^{5}$ not least because it would then basically mean the verse is literally saying that we were created from Adam (the single soul) and a female and a male-surely a most peculiar sentence construction. I find it easier to relate to the other popular interpretation of "dwelling-place" and "repository" as our temporary life on earth and final resting place after death, but not as they appear in this verse partly because of how similar it is to 30:21, and partly since issues of human life, death and resurrection as "proofs of God" have just been covered in the first verse in this very series, 6:95: "...He brings forth the living from the dead, and the dead from the living...”.

I might also add that not connecting with the interpretation that relates to human "pairs" or "mates" would be a missed opportunity, because I find it a wonderful reiteration of the intimate partnership intended by God when fashioning the human couple.

I believe this to be a good example of the importance of reading a verse within the context of the verses before and after it, but also of listening for the nuances of the Qur'an overall on a given theme-in

\footnotetext{
${ }^{5}$ See commentary on different interpretations of verse 6:98 in Nasr, Seyyed Hossein (editor-in-chief) et al. 2015. The Study Quran: A New Translation and Commentary. New York: HarperCollins Publishers, 376-77.
} 
this case, the intended relationship between the human couple. To do this, a reader must be willing to allow both the mind and heart to relax sufficiently so as to be able to enter what I think of as the "psychological mood" of this book of scripture. Not to compare the sublime with the profane, but the attitude in question is not dissimilar to what is required to appreciate an "atmospheric" novel or film, one where the beauty lies in entering the mind-set of the time and place as opposed to following a gripping and sequential plot. Only then can we realise the truth contained in the saying, "the whole is greater than the sum of the parts."

\section{The Heights, 7:189}

It is He who created you (pl.) from a single soul and from it created its mate so he may find tranquillity with her. Then when he covered her, she bore a light burden that she carried easily. Then when she grew heavy, they called upon God "If You give us a healthy child, we will be among the grateful."

\section{..continued in 7:190}

Then when He gave them a healthy child, they ascribed Him partners in what $\mathrm{He}$ had given them. God is exalted above the partners they ascribe.

Verse 7:189 is the only verse on the creation of human beings that seems to specifically address the male human being, since it is a precursor to describing the act of procreation as shown by the flow of the verse: the point being, as the rest of 7:189 and the subsequent verse 7:190 show, to denounce those men and women who renege on their promise to God after $\mathrm{He}$ has answered their most ardent prayer-in this example, that they be granted a healthy child. These two verses are an inevitable prompt for a couple of further remarks:

- There is no suggestion, in other words, in any of the verses on human creation (shown in this section), that men were God's primary object of creation, their "mates" a secondary act.

- Nor can men claim exclusive descent from Adam and attribute women's natures exclusively to Eve: as we have already seen in earlier verses, all men and all women come from both Adam and 


\section{Eve, and the nature of all men and all women (including Adam and Eve) traces back to the divine breath. ${ }^{6}$}

I raise these two fallacies as they are not uncommon in the popular parlance here and there, despite the Qur'anic evidence against them.

The Bees, 16:72

And God made for you (pl.) mates from your own souls, and made for you from your mates children and grandchildren, and provided you with good things.....

The Byzantines, 30:21

And among His signs is that He created mates for you (pl.) from your own souls so that you may find tranquillity in them, and established between you love and compassion. In this there are signs for people who reflect.

The above verse was already cited in the discussion of 6:98 and the natural meaning there of men and women being a "dwelling-place" and a "repository" for one another.

Creator, 35:11

And God created you (pl.) from dust, then from a drop, then He made you into pairs...

Verse 35:11 is striking because it skips over all mention of one soul coming from another or all souls coming from a single (original) soul to describing God's creation of humankind as a project of creating human couples, period. Here, the male and female are explicitly equal parts of the whole.

The Throngs, 39:6

He created you (pl.) from a single soul and then made from it its mate...

Consultation, 42:11

Creator of the heavens and the earth, He has made for you (pl.) mates from your own souls...

${ }^{6}$ On God breathing of His Spirit into Adam, see Qur'an 15:28-29, 32:7-9 and 38:72. 
The Private Rooms, 49:13

Oh humankind: We have created you (pl.) from a male and a female, and made you into nations and tribes so you may get to know one another. Surely the most honourable among you in God's eyes is whoever is the most reverent among you. And God is All-Knowing, Ever-Aware.

Verse 49:13 re-frames what we have already heard in several of the earlier verses: that all men and women come from Adam and Eve equally. It proceeds to spell out that human equality cuts across cultures and ethnicities, with the only difference among us in God's eyes stemming from the quality of each person's faith. Perhaps most interestingly-though not the subject of this book-God is explicit here that our cultural diversity and racial diversity exist by divine decree and were intended to enrich and inform the human experience.

\section{The Star, 53:45}

And that He created the two mates - the male and the female.

\section{Resurrection, 75:39}

And ( $\mathrm{He})$ made it (the human being) into two mates-the male and the female.

\section{The Tiding, 78:8}

And we created you (pl.) in pairs.

As with 35:11 above, the reference in 78:8 is directly to the creation of the human couple as the consequential act of creation, with the male and female as equal parts of the whole.

Moreover this verse is the third of eleven consecutive verses listing "proofs of God", as it were, reminiscent of the flow of 6:95-99 discussed above, once again underlining the human pair of male and female as a pillar of creation. The points made in the flow of verses 78:6-16 are as follows:

- God made the earth a place of rest

- and the mountains firm.

- And He created us in pairs.

- And made sleep for repose

- and made night a covering

- and made day for livelihood. 
- And built seven strong heavens above us

- and made a radiant lamp

- and sent water pouring down from rain-clouds

- to produce grain and plants

- and lush gardens

\section{The Night, $92: 3$}

By Him who created the male and the female.

This is another of those verses that is part of a list of "proofs of God", for lack of a better phrase, where the two genders or the human couple is again cited as an example of God's unique transcendence and beneficence. But this is a more succinct list than the previous examples as this opening argument of chapter 92 then proceeds to make very direct "good vs bad" statements. The points made in the flow of verses $92: 1-11$ are as follows:

- By the night as it enshrouds,

- By the day as it brightens,

- By Him who created the male and the female:

Followed immediately by

- Truly people's endeavours are diverse.

- As for those who give and are reverent

- and who believe in goodness,

- their path will be eased unto a state of ease.

- But as for those who are miserly and think themselves self-sufficient

- and who have no faith in goodness,

- their path will be eased unto a state of hardship,

- and their wealth will not help them when they die.

The Pushback of Alleged hadith on Women's Origin: Crooked as a Rib!

Now given all these references in the Qur'an to Adam and Eve having been created from the same soul containing the divine breath, and to all men and women emanating equally from Adam and Eve, and to 
the equality of both members of the human pair, what should be our reaction if someone cites an alleged hadith from Bukhari's compilation where the Prophet supposedly said that woman was created from a crooked $\mathrm{rib}^{7}$ and so if one tries to "straighten" her, she will break just as surely as a rib would, therefore man would do best to accept her flaws so he can enjoy her for what she is? Insult aside, no matter who supposedly transmitted this and no matter how strong or weak the transmission chain was declared to be in Bukhari's and other hadith compilations, ${ }^{8}$ it makes no sense to accept this supposed "badith" when a) it flies in the face of everything the Qur'an tells us about the fundamental nature of women and b) history, our current world and my own life experience are replete with many admirably principled and moral women in my life and across the globe.

\section{"From Your Own Souls"}

A note on the translation of one particular phrase that recurs in several verses above is in order here. The Arabic phrase "from your own souls" so often used in the Qur'an in reference to the creation of human "mates" or "pairs" has often been translated as "from yourselves". This may convey a good enough meaning, but it does not convey the level of intimacy clearly intended by the Author in verses that convey ideas like "He created you (pl.) from a single soul and from it created its mate", which readily conjures up the familiar notion of a soul-mate.

But I am more disheartened by translations that render "from your own souls" into "from among yourselves", as this seems to thoroughly rupture the intimacy I hear in the Arabic original, moving the meaning of the phrase from the spiritual to the sociological realm. I have to believe that many English translations rely and build on one another-as I have in fact done myself to a good extent-and in the process of such a mammoth

${ }^{7}$ The biblical story of Eve's creation from the rib of Adam cannot be found in the Qur'an. That said, I do not necessarily find this a contradiction as "rib" also depicts intimacy and sameness in my view, and human creation is both a tangible and an intangible process as seen in Qur'anic references to the creation of the human being from clay and water but also from divine breath. The problem with the "crooked rib" hadith though is that Jewish lore (the Isra'iliyyat) then in circulation and accessible to hadith compilers arguably had its own biases, and "hadith" seemed to borrow from it selectively, as has been widely noted even by early Islamic scholars such as Tabari, among others.

${ }^{8}$ Stowasser, Barbara Freyer. 1994. Women in the Qur'an, Traditions, and Interpretation. New York: Oxford University Press Inc., 32. 
task as translating the entire Qur'an, perhaps some nuance existing in the Arabic has sometimes been lost as linguistic/translating custom has asserted itself.

Lastly, it must be mentioned that the word for "soul" (nafs) is a feminine noun in Arabic (there are no gender-neutral nouns). So it is particularly telling when some English translations refer to the soul using the masculine "he", obviously not even content to adopt the grammatically correct gender-neutral form "it" that I have used. Anything to move as far away as possible from "she", it would seem!

\section{All Life on Earth Was Created in Pairs}

In combing through the Qur'an for references to women, I could not help but notice the large number of times the word "pair" or "mate" occurs" (this is the Arabic zawj, which as a reminder can denote both "pair" and "one of a pair" i.e. mate or spouse, depending on context). However, not all such references relate to men and women or even to animals, as the reference is often to plants and fruit. Where this is the case, English translations usually render "pair/mate" as "kind", as in "kinds of plants or fruit", as it would sound too weird to say "pairs of plants or fruit".

I came across an enlightening footnote about this issue in one of the more interesting English translations and commentaries of the Qur'an, ${ }^{10}$ which brutally exposed to me the fact that I had never paid much attention in biology class. As most readers will likely know though, plants usually have both male and female sex organs co-existing within themselves, though some will have them in separate flowers of the same plant. In rare cases, the reproductive organs are found in separate, unisexual plants of the same species. Anyway, I was relieved to find an explanation for what had seemed to me a strange deployment of the concept of the male and female pair in the Qur'an!

It is significant that the Qur'an makes reference to all of God's earthly creation in terms of two sexes, explicitly making "the sexual pair" the fundamental building block in its creationist narrative. And if the human pair

\footnotetext{
${ }^{9}$ The word for "pair" or "mate" (zawj) appears in numerous references to the natural world beyond humans and animals, such as in 13:3, 20:53, 22:5, 26:7, 31:10, 50:7 and 55:52.

${ }^{10}$ Asad, Muhammad. 2003. The Message of the Qur'an. Bristol, England: The Book Foundation, 399.
} 
is at the apex of this creation, then both members of that pair-men and women - are in an exceptionally privileged position. Here are just a few of the many examples of this to be found in the Qur'an:

Ya Sin (uncertain meaning), 36:36

Glory be to He who created all the pairs-those that grow from the earth and those from their souls - and those they do not know about.

Ornaments of Gold, 43:12

And $\mathrm{He}$ who created all the pairs.

The Scattering Winds, 51:49

And of every thing We have created two mates, so that you (pl.) might reflect.

\section{What Explains Societal Deviation from the QuR'anic Pillars of Creation?}

In light of the evidence above from the Qur'an itself regarding the essential nature of women being identical to that of men, what could possibly explain the treatment of women as second-rate beings in some Muslim communities? I can think of a number of possible explanations.

- Many Muslims do not actually read the Qur'an, and local or imported trends fill the vacuum.

Scripture always requires a significant effort on the part of a reader due to the density of its content and complex structure, making it anything but an easy read whatever the religion in question. And while the tradition of reading the Qur'an from beginning till end every Ramadan is widespread among Muslims, I know from personal and others' experience how one can read it yet miss out on key messages when the focus is on finishing the book within a month.

Additionally, it is a most unfortunate fact that much of the Muslim world is illiterate, a sad irony for the followers of a religion so directly based on a book. While literacy rates vary widely from one Muslimmajority country to another and many across the Middle East and Asia are in fact highly literate by global measures, some of the more populous or strategic countries (for varying reasons) nevertheless have very high rates of illiteracy including Afghanistan (61.8\%), Mali 
(61.9\%), Pakistan (41.3\%), Bangladesh (38.5\%), Yemen (29.9\%), Morocco (27.6\%), Egypt (24.8\%), Sudan (24.1\%), Iraq (20.3\%), Algeria (19.8\%), and Tunisia (18.2\%). ${ }^{11}$ Elsewhere, populous countries with significant Muslim populations where the illiteracy rate is also high include Nigeria (40.4\%) and India (27.9\%). Contrast that for a moment with overall illiteracy rates in regions such as Latin America and the Caribbean (6.8\%) or Europe and Central Asia (1.9\%). ${ }^{12}$ Some reports have suggested that close to $40 \%$ of the Muslim world is illiterate. ${ }^{13}$

A further complication is that even among the literate in many countries, such as in South Asia, many people prefer to spend their time listening to and memorising the Qur'an as the word of God in the original Arabic for its intrinsic divine blessing (baraka), which they feel becomes an act of internalising God far superior to reading the Qur'an in another language. This makes many people particularly dependent on hadith, however relayed or selected.

The point is this: it is most probable that relatively few of the world's Muslims read the Qur'an anyway, never mind their degree of commitment or concentration when they do.

- Many Muslims read the Qur'an technically but not reflectively, because they are familiar with the Arabic alphabet but not with Arabic as such.

For example, readers of Urdu or Farsi or Uzbek may recognise the Arabic script sufficiently well to read it, but unless they have studied the language, they would have to rely on others to tell them what it actually says - such as others who may have their own agenda or be themselves influenced by others' agendas or who are simply misinformed. This is like someone who knows only English trying to read French, German or Portuguese, all of which use the Latin alphabet. Why would Muslims who do not know Arabic even try to read the Qur'an in the original Arabic, one might ask? Again, because Muslims believe that there is an intrinsic divine blessing (baraka) in repeating the direct word of God as He chose to communicate it to us. I should

${ }^{11}$ United Nations Development Programme. 2017. Human Development Report 2016, 230-233. The illiteracy rates cited are for the population aged 15 years and above.

${ }^{12}$ Ibid., 233. Central Asia consists of five Muslim-majority countries with highly literate populations.

${ }^{13}$ The Union of News Agencies (UNA, formerly The International Islamic News Agency). 2015. www.iinanews.com. January 14. 
add the clarification that this baraka nonetheless requires that the heart be sincere in the effort and one is not simply going through the motions, otherwise surely the blessing will not be forthcoming whether one understands the Arabic language or not.

But I also believe just as firmly that this reading effort-or indeed the rote memorisation of the Qur'an so common in many religious schools - does not absolve anyone of the duty of trying to genuinely understand what the Qur'an says, that we must try to meet God halfway, so to speak, by doing our bit and making the effort not just to read, recite, or repeat-but also to understand!

- Many Muslims (and others) read translations of the Qur'an that are either heavily influenced by an agenda, or predominantly influenced by accepted cultural norms.

In today's world, this is in fact the issue of greatest concern with respect to Muslims' relationship with the Qur'an. Although the vast majority of egregious ideas within Islam today appear to have come out of the Arabic-speaking world in the latter part of the twentieth century, with Arabs tending to read the Qur'an through the lens of modern Arab experience with statehood and governance, it is a fact that less than $18 \%$ of Muslims in the world are Arab. This means that any spreading of such ideas globally must be primarily taking place in other languages. Passive ignorance or limited knowledge because of not being able to read or fully understand the Qur'an is one thing, but discrimination, intolerance and perhaps even violence due to misinformation is quite another. As explained in the Preface, my experience with some English translations, for example, is a significant factor shaping this book.

Once the essential nature of something is established, there really should be no confusion over its worth as such. Thus in an ideal world, this book on women in the Qur'anic worldview would end right here.

However our world is far from ideal, and women in particular have borne the brunt of unfavourable treatment, time and again, across history and cultures. It is bad enough for society to discriminate against some of its members, but positively egregious to do so while claiming that it is what God wants, adding insult to injury. And it is this that makes it necessary for me to continue writing, which I regret to some extent. I say this 
because while it is important to address the myths and other perversions we have all heard of, I genuinely resent having to raise unpleasant topics in a book that is ultimately about God, who is all things beautiful to me and who could not be further removed from the unsavoury blame assigned to Him for our own shortcomings.

Open Access This chapter is licensed under the terms of the Creative Commons Attribution 4.0 International License (http://creativecommons.org/licenses/ by $/ 4.0 /$ ), which permits use, sharing, adaptation, distribution and reproduction in any medium or format, as long as you give appropriate credit to the original author(s) and the source, provide a link to the Creative Commons licence and indicate if changes were made.

The images or other third party material in this chapter are included in the chapter's Creative Commons licence, unless indicated otherwise in a credit line to the material. If material is not included in the chapter's Creative Commons licence and your intended use is not permitted by statutory regulation or exceeds the permitted use, you will need to obtain permission directly from the copyright holder.

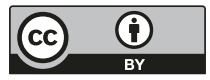

